\title{
Analyzing Bottom-Up Budgeting and Assistance to Disadvantaged Municipalities Program: Toward Participatory Budget Implementation in the First Legislative District of Nueva Ecija in the Philippines
}

\author{
Ronnel Santarita Ubungen \\ Department of the Interior and Local Government (DILG) \\ E-mail: ron.dilgne@gmail.com \\ Vilma B. Ramos (Corresponding author) \\ College of Public Administration and Disaster Management \\ Nueva Ecija University of Science and Technology \\ Cabanatuan City 3100, Philippines \\ E-mail: vilma_ramos05@yahoo.com
}

\author{
Rosemarie Riguer Casimiro \\ College of Public Administration and Disaster Management \\ Nueva Ecija University of Science and Technology \\ Cabanatuan City 3100, Philippines \\ E-mail: rosemaricasimiro@yahool.com
}

Received: Jun. 18, 2020 Accepted: Jul. 30, 2020 Online published: Sep. 13, 2020

doi:10.5296/jpag.v10i3.17689 URL: https://doi.org/10.5296/jpag.v10i3.17689

\begin{abstract}
From 2014 to 2016, the Province of Nueva Ecija has been a constant beneficiary of the Bottom-up Budgeting $(\mathrm{BuB})$ program. However, the change in administration and priority programs since June 2016 has resulted not only in the change in nomenclature from BuB to
\end{abstract}


Assistance to Disadvantaged Municipalities (ADM) Program but also to the shift in focus in terms of budget share and activity options. While both programs are into breaking the cycle of poverty and empowering the local communities, there are differences among the two that needs further attention. The paper evaluates the implementation of the $\mathrm{BuB}$ program in the first legislative district of Nueva Ecija from 2014 to 2016 and analyzes the trend as as bases for the crafting of programs at par with the recent and future developments. The study employed descriptive qualitative research design particularly, content analysis to answer the research question. The study found out that a more responsive ADM program entails greater participation from the stakeholders such as civil society organizations with the technical guidance of the local government units.

Keywords: Bottom-up Budgeting, Grassroots Participatory Planning Process, Assistance to Disadvantaged Municipalities, Civil Society Organizations, Local Development Planning, Local Development Council, Planning and Budgeting

\section{Introduction}

Every organization aspires to secure enough budget to continuously operate (Bolojan, 2011). The same also holds true with the operations of the government (The 1987 Philippine Constitution). From centralized decision-making, the Philippine government explores varied options on how the budget can be maximized to realize its thrusts. The Aquino Administration saw a window of opportunity through an approach to budgeting known as bottom-up budgeting. Using this approach, the bottom-level managers at the barangay, municipal, and city levels were given the opportunity to propose programs needed at the community level (Decker, 2008; DBM-DILG-DSWD-NAPC Joint Memorandum Circular No. 7, Series of 2015). According to Belch and Belch (2004), this budgetary approach determines the objectives first then the required budget.

The BuB (Bottom-up Budgeting) is a program launched during the Aquino administration that aims to provide financial assistance to local government units (Manasan, 2016). It aims to improve the delivery of basic services to the community by funding projects and activities related to the provision of potable water, local access roads, evacuation center, livelihood, skills training, education, and health facilities, among others. It is characterized as participatory or budgeting which conforms to a set of structured methods of involving citizens in the allocation of funds for public use (Bartocci, 2016).

The program is meant to empower the grassroots communities and their respective local governments. The new approach allows local government units to directly implement projects instead of following the conventional (top-down approach) in which projects, activities, and funds are coursed through the national government agencies. The measure also strengthens the link of accountability between the LGUs and their constituents. According to Thindwa, (2006), public participation gives people from the marginal sector of the society a voice to influence budgeting and governance. It makes the budget share more responsive to the needs of the community; enhances good governance practices as it makes budgeting more transparent and the persons or offices in-charge accountable for their decisions and the outcomes; and, ultimately, improves the effectiveness of service delivery. 


\section{Macrothink}

The Province of Nueva Ecija in Region III adopted the BuB from Fiscal Years 2014 to 2016. From the budget shares of $\mathrm{P} 217,431,217.04$ in 2014; $\mathrm{P} 343,079,384.17$ in 2015; and $\mathrm{P} 422,097,624.64$ in 2016 , the province was able to support 112 projects in 2014, 174 projects in 2015 , and 193 projects in 2016.

Meanwhile, the $\mathrm{BuB}$ when restructured into Assistance to Disadvantaged Municipalities (ADM) Program also underwent procedural reforms. This "catch-up" mechanism aims to provide financial aid to municipalities through the projects included in their local development plans and in accordance with the project list specified in the DILG-DBM Joint Memorandum Circular No. 2017-3 issued on May 23, 2017.

To optimize the use of the fund and to still avail of the budget from the ADM program, this paper aims to investigate the BuB implementation in the first Legislative District of Nueva Ecija, particularly the gaps and challenges in the implementation. While there are existing researches regarding $\mathrm{BuB}$, they put emphasis on the national scale and provide limited discussion on the situation on the ground especially on the municipal level. The findings will be significant toward enhancing the new ADM Program and better local-level planning.

\subsection{Objectives of the Study}

The study analyzes the BuB implementation to serve as a tool to enhanced Grassroots Participatory Planning Process or the ADM Program.

Specifically, it seeks to:

1. Review the implementation of $\mathrm{BuB}$ and $\mathrm{ADM}$ in five (5) municipalities in the $1 \mathrm{st}$ District of Nueva Ecija;

2. Determine the effectiveness of the BuB implementation in terms of process and policies;

3. Determine the best practices and challenges encountered in the implementation of BuB; and

4. Propose recommendations based upon the experiences derived from $\mathrm{BuB}$ process to improve the implementation of ADM.

\subsection{Research Framework}

Shown on Figure 1 is the framework which guides the analysis of the variables. It also highlights the concepts used and the elements necessary to answer the objectives earlier presented. 
INPUT

PROCESS

OUTPUT

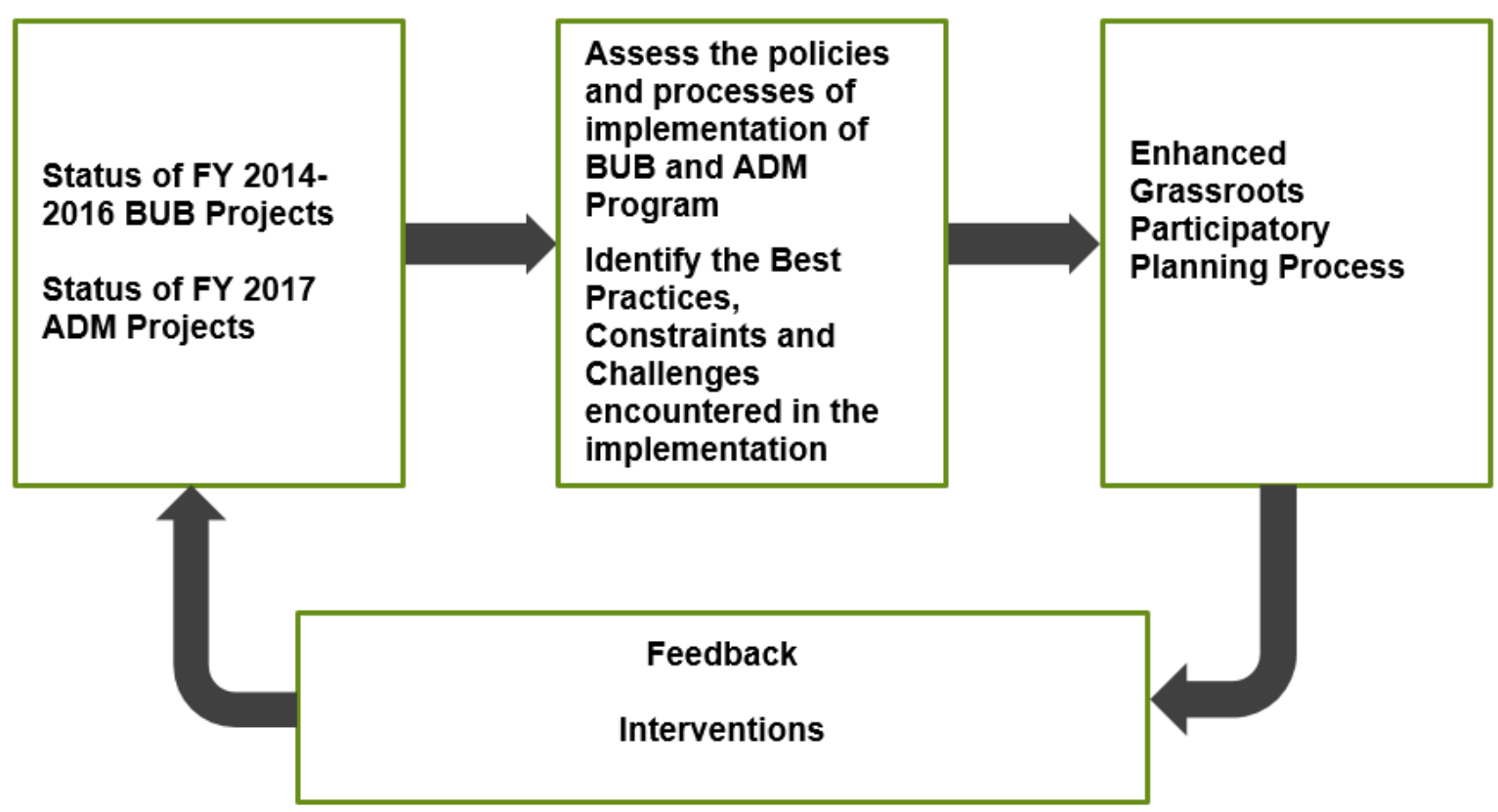

Figure 1. Research Framework

The implementation of BuB for fiscal years 2014 to 2016 and the ADM for fiscal year 2017 in the first legislative district of Nueva Ecija are evaluated, assessed and compared to come up with the enhanced Grassroots Participatory Planning Process in the succeeding years of implementation. The inputs considered were the number and type of projects implemented and the amount of BUB funds generated. The process entails the assessment of the policies and processes of implementation of the BUB and ADM Program. Moreover, information on the best practices, challenges, and constraints encountered during the implementation phase will be collected and feedback will be provided upon analysis of data as additional input to decision-making and policy development in the locality.

\subsection{Theoretical Framework}

The study was anchored on the Theory of Incrementalism which promotes the concept of budgeting for growth (Schick, 1990). It defined budgeting as a bottom-up process with marginal adjustments on an annual basis; by agency rather than by broader aggregates; and by annual changes rather than over longer time periods (LeLoup, 1978). Incrementalism likewise emphasized stability and growth, focusing on bottom-up micro-budgeting as explanation of how the government makes public policy (LeLoup et al., 1998).

\section{Methodology}

The researchers employed a descriptive-qualitative method of research in assessing the policies and processes of BuB and ADM Programs. Data mining was employed by analyzing the contents of available secondary information sources. To examine the effectiveness of the municipalities in implementing the $\mathrm{BuB}$, secondary data on both physical and financial status 
of the projects were collected and processed. Moreover, the LGUs' best practices, challenges, and constraints encountered in the implementation of $\mathrm{BuB}$ and $\mathrm{ADM}$ were collected from the responses of the DILG officers.

\subsection{Sample and Sampling Design}

The data of the five (5) LGUs from the 1st Congressional District of Nueva Ecija representing each income class $\left(1 \mathrm{st}, 2 \mathrm{nd}, 3 \mathrm{rd}\right.$, 4th and $\left.5^{\text {th }}\right)$ were the collected and analyzed. The list of participating LGUs is shown on Table 1.

Table 1. Selected LGUs from $1^{\text {st }}$ District of Nueva Ecija based on their income class

\begin{tabular}{|l|l|}
\hline \multicolumn{1}{|c|}{ Income Class } & \multicolumn{1}{c|}{ Municipalities } \\
\hline $1^{\text {st }}$ & Cuyapo \\
\hline $2^{\text {nd }}$ & Aliaga \\
\hline $3^{\text {rd }}$ & Sto. Domingo \\
\hline $4^{\text {th }}$ & Quezon \\
\hline $5^{\text {th }}$ & Nampicuan \\
\hline
\end{tabular}

The first district of Nueva Ecija was purposively selected as the location of the study since this is the only district among the four (4) Congressional Districts in Nueva Ecija where all LGUs are classified as municipalities. It is the only district in the province which satisfied the criteria of having homogenous and comparable samples.

\subsection{Method of Data Collection}

The researchers administered questionnaires to the Department of Interior and Local Government (DILG) Officers assigned in the identified LGUs. The secondary data were the reports on the budget received from National Government Agencies (NGAs); Accomplishment Reports; and issuances such as Joint Memorandum Circulars (JMCs). Moreover, Focus Group Discussion (FGD) was conducted to those who were involved in the project implementation. The researchers had an interview with CSOs to identify their participation in BuB and ADM sometime in January 2019.

\section{Results and Discussion}

The implementation of BuB FY 2014-2016 projects and ADM FY 2017 projects and their processes were evaluated, assessed, and compared to the provision of the available Joint Memorandum Circulars issued by the DILG and DBM. The issuances detail the processes involved in Grassroots Participatory Planning particularly, the BuB. 


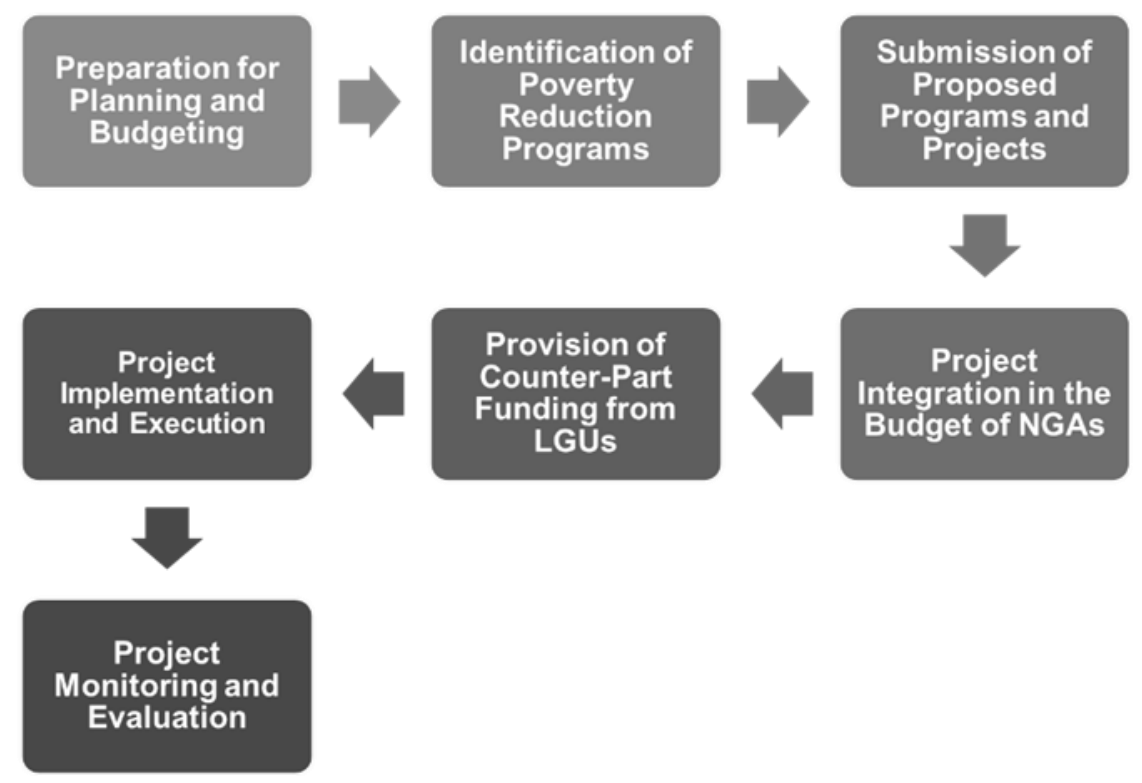

Figure 2. Process Flow of BuB

The $\mathrm{BuB}$ process begins with the planning phase and ends with the project sustainability phase. The DILG and National Anti-Poverty Commission (NAPC) are the lead agencies assigned in organizing the implementation scheme at the local level.

The process starts with the DILG and NAPC conducting CSO Assembly to orient the CSOs of their roles and responsibilities under the BuB program. They will elect among themselves the officers of Local Poverty Reduction Action Team (LPRAT) who will take the lead in the formulation of the Local Poverty Reduction Action Plan (LPRAP). Thereafter, programs and projects which are intended to resolve problems such as hunger, poverty, disaster risk reduction, and access to basic services are identified and considered for inclusion in LPRAP. The representatives coming from the LGU and the CSOs shall be of equal number in the LPRAT. To promote gender sensitivity, $40 \%$ of the total membership must be composed of women.

The LPRAP signed by at least three CSO members of the LPRAT is then submitted to the local Sanggunian for adoption and to the respective Regional and National Poverty Reduction Action Team for review and approval of the proposed programs and projects. Once approved, these projects may be funded in the Budget to be included in the General Appropriations Act of the succeeding year.

The LGUs are required to provide counter-part funding based on the total amount of assistance given to them: $30 \%$ of project cost for highly urbanized cities; $20 \%$ for component cities; $15 \%$ for municipalities from 1st-3rd class; and $5 \%$ for municipalities from 4th-6th class. Before the fund is released, the recipient LGU must present documentary requirements such as feasibility studies, program of works, and detailed engineering design.

The representative of the Civil Society Organizations which are members of the LPRAT also performs crucial role in the execution of the funded project. The CSO representatives observe 
the procurement of materials, attend quarterly meetings of the LPRAT, and report the status and progress of the projects.

Evaluation of the status, progress, and problems encountered is also important. Usually, a group composed of LGU and CSO representatives visit BuB project sites for monitoring. The LGU schedules consultation with the CSOs regarding the status of the BuB projects being implemented while the CSOs submit their analysis and evaluation to the NGA concerned regarding the issues related to the project execution. Both the NGA and CSOs may publish final evaluation reports to achieve greater transparency.

The number of projects implemented by identified LGUs in District 1 is summarized in Table 2 while the amount of funds downloaded to LGUs is shown in Table 3. Before the BuB Program was introduced, LGUs utilized the 20\% Development Fund from their Internal Revenue Allotment (IRA) to finance their development projects. Funding allocations from the $\mathrm{BuB}$ program to all concerned LGUs helped a lot in financing priority development projects of LGUs, thus, contributed to the overall poverty alleviation. Sto. Domingo and Quezon have the greatest number of BuB projects implemented from 2014-2016, both having 20 priority projects. They received funds from NGAs amounting to $\mathrm{P} 40,250,000.00$ and $\mathrm{P} 37,818,500.00$, respectively. Cuyapo has the least with 12 projects amounting to $\mathrm{P} 29,000,000.00$.

Table 2. Number of Projects implemented under BuB

\begin{tabular}{|l|l|l|l|l|}
\hline \multirow{2}{*}{ LGU } & \multicolumn{4}{|l|}{ BUB PROJECTS } \\
\cline { 2 - 5 } & 2014 & 2015 & 2016 & TOTAL \\
\hline Cuyapo & 2 & 4 & 6 & 12 \\
\hline Aliaga & 3 & 5 & 9 & 17 \\
\hline Sto. Domingo & 5 & 8 & 7 & 20 \\
\hline Quezon & 6 & 5 & 9 & 20 \\
\hline Nampicuan & $*$ & 6 & 9 & 15 \\
\hline TOTAL & 16 & 28 & 40 & 84 \\
\hline
\end{tabular}

\section{* Non-BuB Recipient}

Generally, there is an increasing trend in the number of projects implemented and the amount received per GAA from 2014-2016 (The General Appropriations Act FY 2014-2016). However, it does not imply that the higher the number of projects implemented would mean the higher amount of funds received from NGAs (Tables 2 and 3). Some LGUs focus on a few projects with a high amount resulting in higher impact than many projects having a small amount with low impact.

Table 3. Amount of Projects implemented under BuB

\begin{tabular}{|l|c|c|c|c|}
\hline \multirow{2}{*}{ LGU } & \multicolumn{4}{|c|}{ BUB PROJECTS (in million pesos) } \\
\cline { 2 - 5 } & 2014 & 2015 & 2016 & TOTAL \\
\hline Cuyapo & $2,000,000.00$ & $12,000,000.00$ & $15,000,000.00$ & $29,000,000.00$ \\
\hline
\end{tabular}




\begin{tabular}{|l|c|c|c|c|}
\hline Aliaga & $10,000,000.00$ & $9,500,000.00$ & $12,000,000.00$ & $31,500,000.00$ \\
\hline Sto. Domingo & $12,750,000.00$ & $12,500,000.00$ & $15,000,000.00$ & $40,250,000.00$ \\
\hline Quezon & $13,300,000.00$ & $11,518,500.00$ & $13,000,000.00$ & $37,818,500.00$ \\
\hline Nampicuan & $*$ & $8,500,000.00$ & $15,000,000.00$ & $23,500,000.00$ \\
\hline
\end{tabular}

* Non-BuB Recipient for 2014

For 2014, only 17 LGUs were selected by NGAs as recipients of BuB funds. In 2015 and 2016, all LGUs were included to receive funds amounting to $\mathrm{P} 12,500,000.00$ and $\mathrm{P}$ $15,000,000.00$ respectively, based on the standard appropriation of the National Government. Based on the given data (Table 3), the discrepancy in the amount received by the LGUs in 2015 and 2016 was caused by the unimplemented/dropped projects.

Table 4. Number of Projects implemented under different NGAs

\begin{tabular}{|c|c|c|c|c|c|c|c|c|c|c|c|}
\hline \multirow[b]{2}{*}{ LGU } & \multicolumn{11}{|c|}{ BUB PROJECTS } \\
\hline & $\begin{array}{c}\mathrm{DIL} \\
\mathrm{G}\end{array}$ & $\begin{array}{l}\mathrm{D} \\
\mathrm{A}\end{array}$ & $\begin{array}{c}\text { DepE } \\
\mathrm{d}\end{array}$ & $\begin{array}{c}\mathrm{DS} \\
\mathrm{WD}\end{array}$ & $\begin{array}{c}\text { DT } \\
\text { I }\end{array}$ & $\begin{array}{c}\text { LGS } \\
\text { F }\end{array}$ & $\begin{array}{c}\text { NAP } \\
\text { C }\end{array}$ & $\begin{array}{l}\text { TES } \\
\text { DA }\end{array}$ & $\begin{array}{c}\mathrm{DO} \\
\mathrm{H}\end{array}$ & $\begin{array}{c}\text { DOL } \\
\text { E }\end{array}$ & $\begin{array}{c}\text { TOT } \\
\text { AL }\end{array}$ \\
\hline Cuyapo & 2 & 3 & 1 & 0 & 0 & 6 & 0 & 0 & 0 & 0 & 12 \\
\hline Aliaga & 3 & 2 & 0 & 2 & 1 & 7 & 1 & 1 & 0 & 0 & 17 \\
\hline Sto. Domingo & 3 & 4 & 2 & 3 & 0 & 4 & 0 & 0 & 2 & 2 & 20 \\
\hline Quezon & 4 & 7 & 0 & 5 & 0 & 2 & 0 & 0 & 2 & 0 & 20 \\
\hline Nampicuan & 0 & 1 & 0 & 2 & 3 & 5 & 0 & 1 & 3 & 0 & 15 \\
\hline TOTAL & 12 & 17 & 3 & 12 & 4 & 24 & 1 & 2 & 7 & 2 & 84 \\
\hline
\end{tabular}

The number of projects implemented per NGAs reflects the priority needs of the beneficiaries (Table 4). Most of the projects identified in the LPRAP were enrolled under Local Government Support Fund or LGSF (24 projects). These projects were implemented by the concerned LGUs since the funds were directly downloaded to them from the DBM. They are responsible for the overall implementation of the projects. Priority Projects being implemented under LGSF are Local Access Roads, Potable Water Supply System, Evacuation Center, among others. The agriculture-related projects (17 projects) displayed the needs of the local farmers for facilities and pieces of machinery to cultivate agricultural products since Nueva Ecija is considered as the Rice Granary of the Philippines.

Table 5. Status of Projects implemented in Selected LGUs

\begin{tabular}{|c|c|c|c|c|c|c|c|c|c|c|c|c|c|c|c|}
\hline \multirow[b]{2}{*}{ Status } & \multicolumn{3}{|c|}{ Cuyapo } & \multicolumn{3}{|c|}{ Aliaga } & \multicolumn{3}{|c|}{ Sto. Domingo } & \multicolumn{3}{|c|}{ Quezon } & \multicolumn{3}{|c|}{ Nampicuan } \\
\hline & 2014 & 2015 & 2016 & 2014 & 2015 & 2016 & 2014 & 2015 & 2016 & 2014 & 2015 & 2016 & 2014 & 2015 & 2016 \\
\hline Completed & 2 & 4 & 6 & 2 & 4 & 9 & 5 & 8 & 7 & 6 & 5 & 9 & 0 & 6 & 9 \\
\hline On-going & 0 & 0 & 0 & 0 & 0 & 0 & 0 & 0 & 0 & 0 & 0 & 0 & 0 & 0 & 0 \\
\hline
\end{tabular}




\begin{tabular}{|l|l|l|l|l|l|l|l|l|l|l|l|l|l|l|l|}
\hline Dropped & 1 & 0 & 0 & 1 & 3 & 1 & 0 & 0 & 0 & 0 & 1 & 1 & 0 & 2 & 0 \\
\hline TOTAL & 3 & 4 & 6 & 3 & 7 & 10 & 5 & 8 & 7 & 6 & 6 & 10 & 0 & 8 & 9 \\
\hline
\end{tabular}

Table 5 reflects the status of projects (completed, on-going, and dropped) being implemented from FY 2014-2016. The DILG, as the oversight agency, monitored the implementation process and the physical status of projects. The DILG Inspection Team and the LPRAT conducted regular project monitoring and site validation of $\mathrm{BuB}$ projects. This is also a way of providing technical assistance to the LGUs and serve as a means in improving the coordination and working-relationship between the LGUs and Inspection Team. Through their combined efforts, project completions are being delivered and attained.

All BuB Projects from FY 2014-2016 are completed. However, some of the projects were considered dropped or unimplemented due to some reasons such as the: a) unavailability of funds to implement the BuB projects particularly in the case of the Department of Health $(\mathrm{DOH})$ and Department of Education (DepEd); and b) unavailability and/or lacking capacity of LGUs to prepare needed Detailed Engineering Design, Certifications, Program of Works, and other documentary requirements to implement the projects caused delayed Implementation of projects and dropping/cancellation of projects to some LGUs.

Table 6. Implementation Constraints and Recommendations in the Implementation of BuB Projects

\begin{tabular}{|c|c|}
\hline Implementation Constraints & Recommendations \\
\hline $\begin{array}{l}\text { Political dynamics and changes in the LGU } \\
\text { administration due to the } 2016 \text { National } \\
\text { Elections caused delays on the project } \\
\text { implementation of some LGUs due to } \\
\text { changes in political priorities and later } \\
\text { resulted in dropping/cancellation of some } \\
\text { projects. }\end{array}$ & $\begin{array}{l}\text { Downloading of funds should be done on a } \\
\text { lump-sum basis rather than on an installment } \\
\text { basis with additional document submissions. }\end{array}$ \\
\hline $\begin{array}{l}\text { Inconsistent list of required documents per } \\
\text { NGAs that led to confusion and late } \\
\text { submission of the said documents. }\end{array}$ & $\begin{array}{l}\text { Adjustment of documentary standards to the } \\
\text { basics and minimum requirements. There } \\
\text { should be a consistent and standardized list } \\
\text { of required documents. }\end{array}$ \\
\hline $\begin{array}{l}\text { Poor coordination among NGOs, CSOs, and } \\
\text { LGUs in the planning process of the priority } \\
\text { projects which resulted to duplication of } \\
\text { projects among agencies and insufficient } \\
\text { project fund allocation particularly those } \\
\text { under NEA, DOE, DEPED, DENR and DA. }\end{array}$ & $\begin{array}{l}\text { Strengthen the collaboration of NGA, LGU, } \\
\text { and LPRAT not only during the planning } \\
\text { process but also during the project } \\
\text { implementation, monitoring and funds } \\
\text { liquidation. }\end{array}$ \\
\hline
\end{tabular}


Problem on the sustainability of the projects after turn-over due to limited funds of the recipients.
NGAs should assist the LGUs to formulate sustainability and maintenance plan to make the projects useful and operational for a longer term of existence

In the initiative and sponsorship of the RPRAT member agencies, the series of provincial summits and consultative meetings were conducted to serve as a venue for the oversight agencies and LPRATs to interface and present the overall status of BuB project implementation and come up with issues resolution and realistic timeline for the completion of BuB projects. Through this activity, implementation constraints, issues and concerns were clarified including the lacking documents, the causes of delayed projects, and the submission of liquidation reports. Moreover, recommendations to further improve its implementation were raised during the said activities.

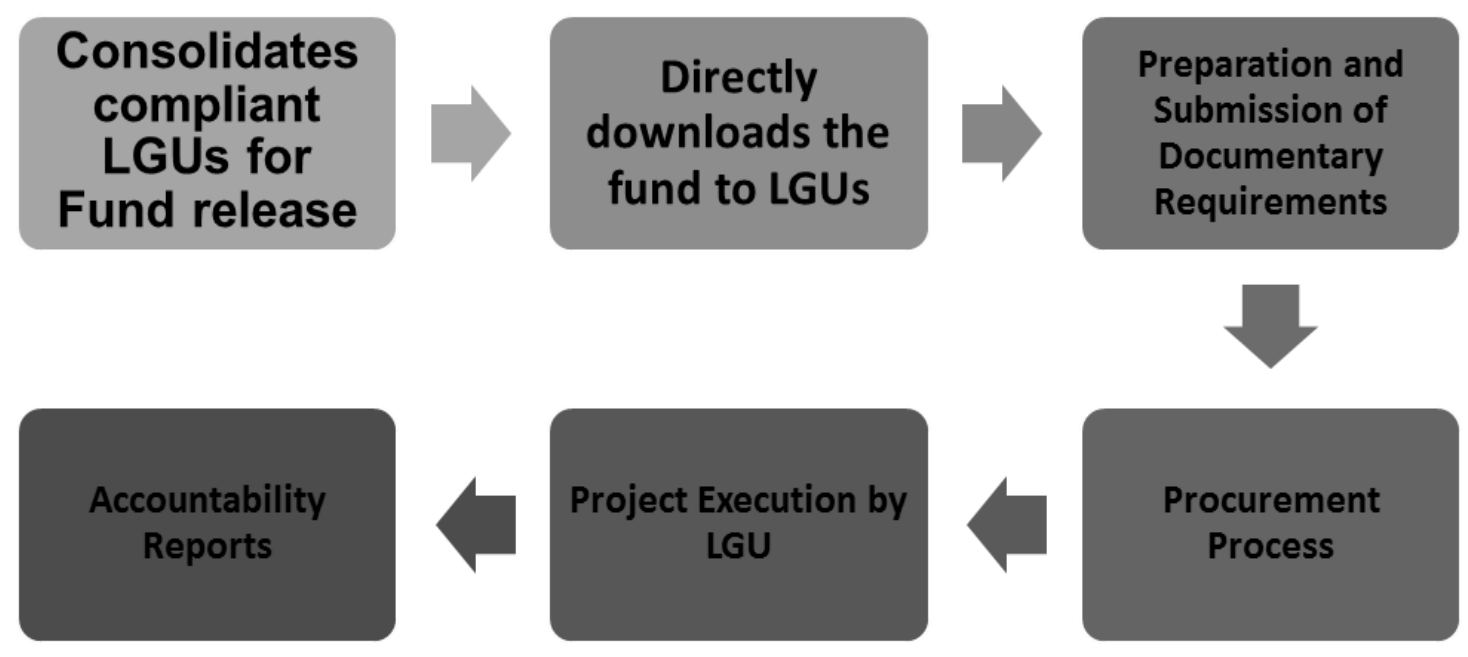

Figure 3. Implementation Process of Assistance to Disadvantaged Municipalities (ADM) Program

Figure 3 shows the process flow of ADM. In the implementation of ADM, all expenses incurred in the conduct of preliminary activities and other administrative cost in the supervision of the project during implementation shall be shouldered by the LGU as their counterpart. The Municipal Accountant shall recognize the completed project as asset of the LGU in accordance with existing accounting rules and regulations.

Upon the receipt of funds, the LGU shall submit the duly notarized LCE Certification stating that all documentary requirements are consistent with national government standards and all bidding documents have been completed and the LGU is ready to proceed with publication of the Invitation to Bid/Advertisement. Moreover, sub-project implementation schedule indicating the procurement and implementation timelines shall also be submitted to the DILG.

All project procurement shall be through competitive bidding, in strict compliance with the 
provisions of RA No. 9184 (Government Procurement Reform Act). Upon submission of the required Notarized Certifications, the LGU shall proceed with procurement, as indicated in the certification and implementation schedule. The DILG and other entities may be invited to observe particularly during pre-bid conferences and/or bid opening. A duly accredited CSO representative who is a signatory to the municipality's list of priority projects shall be invited to sit as an observer in the Bids and Awards Committee (BAC), which will undertake the procurement activities for the implementation of ADM projects.

The LGU shall ensure that the design, plans, specifications, and construction of projects are in accordance with the National Government standards and within the range of costs and a project duration of similar projects being implemented by NGA in the same locality. They shall ensure that quality control and assurance are observed, quality tests are conducted and construction logbook is maintained at the project site, and made it available to DILG during visits and/or as may be requested.

Table 7. Number of Projects implemented under ADM

\begin{tabular}{|l|c|}
\hline \multicolumn{1}{|c|}{ LGU } & $\begin{array}{c}\text { NUMBER OF ADM PROJECTS IMPLEMENTED } \\
\text { DURING F.Y. 2017 }\end{array}$ \\
\hline Cuyapo & 9 \\
\hline Aliaga & 6 \\
\hline Sto. Domingo & 2 \\
\hline Quezon & 1 \\
\hline Nampicuan & 5 \\
\hline TOTAL & 23 \\
\hline
\end{tabular}

In 2017, the Municipality of Cuyapo received the largest amount among five (5) LGUs to implement their nine (9) local access road projects from ADM. Quezon implemented only one (1) project which is the Potable Water System project amounting to $\mathbb{P} 14,235,000.00$ (Table 7 and 8).

Table 8. Amount of Projects implemented under ADM

\begin{tabular}{|l|c|}
\hline \multicolumn{1}{|c|}{ LGU } & ADM PROJECTS F.Y. 2017 (in million pesos) \\
\hline Cuyapo & $15,870,000.00$ \\
\hline Aliaga & $15,576,000.00$ \\
\hline Sto. Domingo & $15,265,000.00$ \\
\hline Quezon & $14,235,000.00$ \\
\hline Nampicuan & $14,556,000.00$ \\
\hline
\end{tabular}

In Nueva Ecija, the DBM downloaded a total amount of $尹$ 417,718,000.00 to fund 91 projects of the 27 municipalities in FY 2017. LGUs were made accountable in the overall implementation of their ADM-funded projects. They ensured that the design, plans, specifications and construction of projects are in accordance with the national government standards and within the range of costs and a project duration of similar projects being implemented by NGA in the same locality. 
Table 9. Types of Projects implemented under ADM

\begin{tabular}{|l|c|c|c|c|c|}
\hline \multicolumn{1}{|c|}{ LGU } & $\begin{array}{c}\text { Local } \\
\text { Access } \\
\text { Road }\end{array}$ & $\begin{array}{c}\text { Potable } \\
\text { Water } \\
\text { System }\end{array}$ & $\begin{array}{c}\text { Evacuation } \\
\text { Center }\end{array}$ & $\begin{array}{c}\text { Small Water } \\
\text { Impounding } \\
\text { System }\end{array}$ & Total \\
\hline Cuyapo & 9 & 0 & 0 & 0 & 9 \\
\hline Aliaga & 5 & 1 & 0 & 0 & 6 \\
\hline Sto. Domingo & 2 & 0 & 0 & 0 & 2 \\
\hline Quezon & 0 & 1 & 0 & 0 & 1 \\
\hline Nampicuan & 5 & 0 & 0 & 0 & 5 \\
\hline TOTAL & 21 & 2 & 0 & 0 & 23 \\
\hline
\end{tabular}

Most of the LGUs identified local access road as their top priority project. The types of projects implemented under ADM FY 2017 are reflected in Table 9. Moreover, the infrastructure project's main purpose is to support the poverty reduction program of the municipalities particularly by providing access to farmers in marketing their farm produced eventually increasing productivity. It also aims to increase agricultural production and upgrade substandard gravel road for safe and economical access that is supportive to other basic services.

Table 10. Status of ADM Projects

\begin{tabular}{|l|c|c|c|c|c|}
\hline \multicolumn{1}{|c|}{ Status } & Cuyapo & Aliaga & Sto. Domingo & Quezon & Nampicuan \\
\hline Completed & 9 & 6 & 2 & 1 & 5 \\
\hline On-going & 0 & 0 & 0 & 0 & 0 \\
\hline Dropped & 0 & 0 & 0 & 0 & 0 \\
\hline TOTAL & 9 & 6 & 2 & 1 & 5 \\
\hline
\end{tabular}

All of the projects under ADM were all successfully implemented (Table 10). The concerned municipality is the primary responsibility for ensuring the implementation of the project in accordance with the approved design, plans and specifications. There is no on-going or unimplemented projects under ADM. The Municipality of Quezon concentrated all of its funds to only one (1) project which is the Potable Water System. Water is essential in every aspect of human life. However, the local water district has not yet expanded its operations in far-flung areas that is why there is a shortage in potable drinking water. Also, since the residents usually source out their drinking water from deep well with risks of acquiring water-borne diseases like diarrhea, cholera, skin diseases, and hepatitis.

\subsection{Comparative Analysis of BuB and ADM}

A comparative analysis between $\mathrm{BuB}$ and $\mathrm{ADM}$ approaches were shown in Table 11 with emphasis on specific areas of their differences.

Table 11. Comparative analysis of the BUB and ADM 


\begin{tabular}{|c|c|c|}
\hline PARTICULARS & Bottom-up Budgeting (BuB) & $\begin{array}{l}\text { Assistance to Disadvantaged } \\
\text { Municipalities (ADM) }\end{array}$ \\
\hline COVERAGE & All Cities and Municipalities & All Municipalities \\
\hline $\begin{array}{l}\text { PROJECT } \\
\text { IDENTIFICATION }\end{array}$ & $\begin{array}{l}\text { Projects identified by LPRAT } \\
(50 \% \text { CSO and } 50 \% \text { LGU } \\
\text { Officials) and included in the } \\
\text { LPRAP }\end{array}$ & $\begin{array}{l}\text { Projects culled out from the LDIP, } \\
\text { CDP, CLUP or any available LGU } \\
\text { Sectoral Plans }\end{array}$ \\
\hline $\begin{array}{l}\text { PROJECT } \\
\text { MODIFICATION } \\
\text { AND LOCATION }\end{array}$ & $\begin{array}{l}\text { The Proponent LGU may submit a } \\
\text { revised design, specification, } \\
\text { location and other details proposed } \\
\text { in the LPRAP and project brief } \\
\text { through LPRAT letter justifying } \\
\text { such changes signed by the LCE } \\
\text { and } 3 \text { CSOs signatories to } \\
\text { DILG-Regional Office }\end{array}$ & $\begin{array}{l}\text { Not allowed. Project specification } \\
\text { (Name of Project and corresponding } \\
\text { amount) indicated in the Notice of } \\
\text { Authority to Debit Account Issued } \\
\text { (NADAI) from DBM must be } \\
\text { followed. }\end{array}$ \\
\hline $\begin{array}{l}\text { PROJECT } \\
\text { QUALIFICATIONS }\end{array}$ & $\begin{array}{l}\text { To be qualified, the project should } \\
\text { meet the following requirements: } \\
\text { - Provision of Basic Social } \\
\text { Services and attainment of the } \\
\text { Sustainable Development } \\
\text { Goals, including poverty } \\
\text { reduction; } \\
\text { - Hunger Mitigation and } \\
\text { Elimination; } \\
\text { - Job Generation and Inclusive } \\
\text { Local Economic Development; } \\
\text { - Climate Change } \\
\text { Adaptation/Mitigation and } \\
\text { Disaster Preparedness; and } \\
\text { - Budget requests from NGA } \\
\text { shall not be less than } \\
\text { P 500,000.00 per project. }\end{array}$ & $\begin{array}{l}\text { Limited only to eight (8) Projects as } \\
\text { specified in the Menu of Projects: } \\
\text { - Local Access Road, } \\
\text { - Potable Water System Project, } \\
\text { - Evacuation Center and Disaster } \\
\text { Risk Reduction Related } \\
\text { Equipment, } \\
\text { - Small Water Impounding Project, } \\
\text { - Sanitation and Health Facilities, } \\
\text { - Local Bridges, } \\
\text { - Rain Water Catchment Facility, } \\
\text { - Municipal Drug Rehabilitation } \\
\text { Facility. }\end{array}$ \\
\hline ALLOCATION & $\begin{array}{l}\text { Standard Allocation per LGU (尹 } \\
\text { 12.5 M for } 2015 \text { and } 尹 \text { 15 M for } \\
\text { 2016) plus LGU Counterpart: } \\
\text { - Highly Urbanized Cities: } 30 \% \\
\text { of project } \\
\text { - All other cities: } 20 \% \text {, } \\
\text { - } 1 \text { st to 3rd class municipalities: } \\
15 \% \text {, }\end{array}$ & $\begin{array}{l}\text { The budget cap of each covered } \\
\text { municipality is determined by the } \\
\text { following factors: } \\
\text { - equal share of each covered } \\
\text { municipality from the total ADM } \\
\text { allocation } \\
\text { - per capita share of the } \\
\text { municipality; }\end{array}$ \\
\hline
\end{tabular}




\begin{tabular}{|c|c|c|}
\hline PARTICULARS & Bottom-up Budgeting (BuB) & $\begin{array}{l}\text { Assistance to Disadvantaged } \\
\text { Municipalities (ADM) }\end{array}$ \\
\hline & $\begin{array}{l}\text { - } 4 \text { th to 6th class municipalities: } \\
5 \%\end{array}$ & \\
\hline FUND RELEASE & $\begin{array}{l}\text { Funds from DBM are downloaded } \\
\text { to DILG Regional Office. Then, it } \\
\text { obligates the fund upon MOA } \\
\text { signing and releases the } 1^{\text {st }} \text { tranche } \\
\text { to LGUs ( } 80 \% \text { of the total project } \\
\text { amount). The remaining } 20 \% \text { will } \\
\text { be released when the LGU } \\
\text { liquidates the } 80 \% \text { fund. }\end{array}$ & $\begin{array}{l}\text { Funds from DBM thru the Bureau of } \\
\text { Treasury are directly downloaded to } \\
\text { eligible municipalities upon LGU } \\
\text { compliance of the set of Governance } \\
\text { Conditions. }\end{array}$ \\
\hline $\begin{array}{l}\text { ELIGIBLE LGUS TO } \\
\text { RECEIVE THE } \\
\text { FUNDS }\end{array}$ & $\begin{array}{l}\text { The budget for BuB Projects will } \\
\text { only be released if the following } \\
\text { conditions are being met: } \\
\text { Attainment of Good Financial } \\
\text { Housekeeping and Public Financial } \\
\text { Management. }\end{array}$ & $\begin{array}{l}\text { The municipalities will receive the } \\
\text { assistance once they receive Good } \\
\text { Financial Housekeeping and } \\
\text { completed both the assessment and } \\
\text { adoption of Public Financial } \\
\text { Management. }\end{array}$ \\
\hline $\begin{array}{l}\text { COMPLIANCE TO } \\
\text { GOVERNANCE } \\
\text { CONDITIONS }\end{array}$ & $\begin{array}{l}\text { If City/Municipality is } \\
\text { non-compliant, NGA concerned or } \\
\text { the Provincial Government (PG) } \\
\text { may implement the project. }\end{array}$ & $\begin{array}{l}\text { If the Municipality failed to comply } \\
\text { with the Governance Conditions until } \\
\text { a specified time, the project will be } \\
\text { canceled. }\end{array}$ \\
\hline $\begin{array}{l}\text { MEMORANDUM OF } \\
\text { AGREEMENT }\end{array}$ & $\begin{array}{l}\text { Signed MOA between DILG and } \\
\text { LGU upon submission of required } \\
\text { docs }\end{array}$ & $\begin{array}{l}\text { MOA between DILG and LGU is } \\
\text { NOT required. }\end{array}$ \\
\hline $\begin{array}{l}\text { DETAILED } \\
\text { ENGINEERING } \\
\text { DESIGN/PROGRAM } \\
\text { OF WORKS } \\
\text { APPROVAL }\end{array}$ & $\begin{array}{l}\text { LGU must submit DED/POW after } \\
\text { MOA signing and must be } \\
\text { reviewed and approved by DILG } \\
\text { before the LGU can proceed with } \\
\text { procurement process }\end{array}$ & $\begin{array}{l}\text { Only a notarized LCE Certification, } \\
\text { certifying that DED/POW and } \\
\text { bidding docs are prepared per } \\
\text { National Government Standards } \\
\text { within } 60 \text { days upon LGU receipt of } \\
\text { the fund. LGU may proceed with the } \\
\text { procurement process upon } \\
\text { submission of the certification. }\end{array}$ \\
\hline $\begin{array}{l}\text { BOOKING-UP AS } \\
\text { AN LGU ASSET OF } \\
\text { THE COMPLETED } \\
\text { PROJECTS }\end{array}$ & Not included in the guidelines & $\begin{array}{l}\text { The Municipal Accountant shall } \\
\text { recognize the completed project as an } \\
\text { asset per existing accounting rules } \\
\text { and regulations }\end{array}$ \\
\hline $\begin{array}{l}\text { PROJECT } \\
\text { FEASIBILITY }\end{array}$ & $\begin{array}{l}\text { DILG may conduct site visits and } \\
\text { field validation. }\end{array}$ & $\begin{array}{l}\text { Part of the LCE certification that the } \\
\text { project is feasible to implement. }\end{array}$ \\
\hline
\end{tabular}




\begin{tabular}{|c|c|c|}
\hline PARTICULARS & Bottom-up Budgeting (BuB) & $\begin{array}{l}\text { Assistance to Disadvantaged } \\
\text { Municipalities (ADM) }\end{array}$ \\
\hline & & $\begin{array}{l}\text { e.g., water source has been validated } \\
\text { by the Municipal Engineer and is: } \\
\text { a. Feasible for supplying water to the } \\
\text { intended beneficiaries; and, } \\
\text { b. Potable for drinking or engineering } \\
\text { mitigation measures have been } \\
\text { included in the design to make the } \\
\text { water potable }\end{array}$ \\
\hline $\begin{array}{l}\text { MODE OF } \\
\text { IMPLEMENTATION: }\end{array}$ & $\begin{array}{l}\text { - By Administration } \\
\text { - By Contract } \\
\text { - By Contract for Design and } \\
\text { Build Infrastructure } \\
\text { - Implementation by Partner } \\
\text { Agency }\end{array}$ & $\begin{array}{l}\text { - By Contract through competitive } \\
\text { bidding } \\
\text { - By Administration only after } 2 \\
\text { failed bidding and failed } \\
\text { negotiated procurement }\end{array}$ \\
\hline $\begin{array}{l}\text { RESPONSIBLE FOR } \\
\text { IMPLEMENTATION }\end{array}$ & $\begin{array}{l}\text { LGU and DILG are responsible for } \\
\text { the implementation }\end{array}$ & $\begin{array}{l}\text { LGU is responsible for the } \\
\text { implementation and DILG for } \\
\text { monitoring. }\end{array}$ \\
\hline
\end{tabular}

The process of Bottom-up budgeting promotes transparency and accountability leading to an effective service delivery system for the marginalized sectors. According to the studies conducted by Gabriel (2017), transparency and accountability are enhanced by the commitments of local legislative body members; increases organizational effectiveness and delivery system in the LGUs in the Philippines (Gabriel 2017b; Ong and Gabriel, 2018) and mediates democracy and effective public service delivery (Gabriel, Antonio and Ramos 2019). The program encourages people's empowerment in local development planning to alleviate poverty in the society. BuB increased CSO participation in local governance since they are well-represented and strongly consulted by the LPRAT in the identification of poverty reduction projects. Under ADM, CSOs represent the only $1 / 4$ of the total membership in the Local Development Council. $75 \%$ of which came from government officials and functionaries. Their involvement and participation are limited as shown in Table 12. BuB encouraged CSOs to raise their issues and concerns to the LPRAT and identify possible projects and programs that will solve their problems, hence, enhancing their self-worth and empowerment.

Table 12. Area of Participation of CSOs in BUB and ADM (Thematic Grid)

\begin{tabular}{|c|c|c|}
\hline & $\begin{array}{c}\text { Bottom-up } \\
\text { Budgeting }\end{array}$ & $\begin{array}{c}\text { Assistance to } \\
\text { Disadvantaged } \\
\text { Municipalities }\end{array}$ \\
\hline
\end{tabular}




\begin{tabular}{|l|c|c|}
\hline Participation in CSO Assembly & $\checkmark$ & $\mathrm{x}$ \\
\hline Project Identification & $\checkmark$ & $\mathrm{x}$ \\
\hline Budget Allocation & $\checkmark$ & $\mathrm{x}$ \\
\hline Submission of Project Proposal & $\mathrm{x}$ & $\mathrm{x}$ \\
\hline Implementation of Project & $\checkmark$ & $\mathrm{x}$ \\
\hline Project Inspection & $\mathrm{x}$ & $\mathrm{x}$ \\
\hline Submission of Accountability Reports & $\checkmark$ & $\mathrm{x}$ \\
\hline Project Sustainability & $\checkmark$ & $\mathrm{x}$ \\
\hline $\begin{array}{l}\text { Signatory in the submission of Project } \\
\text { Status Reports }\end{array}$ & $\checkmark$ & \\
\hline
\end{tabular}

Local Government Code seems to presume that if the local governments want to be able to effectively address the most fundamental development needs of their poorest populations, there must be a mechanism by which its citizenry, especially the most marginalized, can provide relevant input to the process because they know well their situation and because they have to realize that they are stakeholders of the projects to be implemented (Manasan, 2016).

\section{Recommendation}

ADM has been only implemented recently and a significant time frame is needed in evaluating the said approach since the necessary framework and processes are not fully in place and still in the process of development. In its current state, the national government and other stakeholders involved in the process must work in fine-tuning the ADM scheme to be more effective in its goals. Moreover, the following are the recommendations of the researchers:

Make ADM Program More Participatory and Responsive. The priority projects being implemented under ADM Program were all culled out from the existing sectoral plans in the LGU. However, these plans were formulated by the Local Development Council wherein CSO participation is limited. CSO membership in LDC should be increased to $50 \%$ similar to LPRAT. There should have clear guidelines and provisions on how to select CSO representatives to LDC who will serve as an active partner in local development planning.

CSO participation in ADM Program needs to be strengthened to promote transparency and accountability in using public funds for development projects. They shall participate not only 
in the planning phase but also in the actual implementation and monitoring of projects. CSOs were tapped by the government in order for their voices to be heard and the data generated from them will be useful in prioritizing poverty reduction projects.

The government shall enhance the capability and capacity of CSOs to have effective participation in the ADM program. Most of them came from the marginalized sector of society with low education and poor access to basic services. They shall be oriented on their roles and responsibilities in promoting the development of their respective communities. Seminars like engineering for non-engineers and basic planning and budgeting shall be conducted and participated by the CSOs to acquire knowledge and skills they need to become an active partner of the government.

The strength and quality of participation of CSOs on development planning and budgeting process depend greatly on their ability to play their roles in making decision that will have an impact to the community (Arnstein 1969).

Therefore, applying the principles and processes of $\mathrm{BuB}$ in enhancing the Grassroots Participatory Planning Process of the current administration, the ADM Program will continue to promote good governance by making the budget of the NGAs more responsive to the needs of the society, it will promote fiscal autonomy and will empower the citizen to become an active partner for local development.

\section{References}

Arnstein S. (1969). A ladder of citizen participation. Journal of the American Institute of Planners 1969, 35, 216-24.

Bartocci, L. (2016). Participatory Budgeting. University of Perugia, Perugia, Italy

Belch, G., \& Belch, M. (2004). Advertising and Promotion, An Integrated Marketing Communications Perspective (6th ed.). New York: McGraw-Hill Companies, Inc

Bolojan, F. (2011). Bottom-up/top-down budgeting. Defense Resources Management in the 21st Century, 6(6), 160-164.

Decker, F. (2008). Top-down vs. Bottom-up Budgeting, 2008. Review.

DBM-DILG-DSWD-NAPC Joint Memorandum Circular No. 7, Series of 2015: Policy Guidelines and Procedures in the Implementation and Monitoring of Bottom Up Budgeting Program for FY 2016 and thereafter

DILG-DBM Joint Memorandum Circular No. 2017-3 Policy Guidelines and Procedures in the Implementation of the FY 2017 Local Government Support Fund-Assistance to Disadvantaged Municipalities (LGSF-ADM) Program.

Gabriel, A. G. (2017). Transparency and accountability in local government: Levels of the commitment of municipal councilors in Bongabon in the Philippines. Asia Pacific Journal of Public Administration, 39(3), 217-223. Accessible at: https://doi.org/10.1080/23276665.2017.1368902.

Gabriel, G. A., \& Gutierrez, M. P. (2017). Praxis in local legislative governance: Measure of organizational effectiveness of the component cities in Nueva Ecija, Philippines. Retrieved 


\section{Macrothink}

Journal of Public Administration and Governance ISSN 2161-7104 2020, Vol. 10, No. 3

from http://www.apjmr.com/wp-content/uploads/2017/04/APJMR;2017.5.2.02.pdf

Gabriel, A. G., \& Ong, D. U. (2018). Linking transparency and accountability to local legislative performance in the province of Nueva Ecija in the Philippines. Journal of Public Administration and Governance., 8(2), 384-396.

Gabriel, A. G., Antonio, M. A., Ramos, V. B., \& Marasigan, J. T. (2019). Transparency and Accountability in Local Governance: The Nexus Between Democracy and Public Service Delivery in the Philippines. Public Policy and Administration Research, 9, 30-36.

LeLoup, L. T. (1978). The Myth of Incrementalism: Analytical Choices in Budgetary Theory. Polity.

LeLoup, L. T., et al. (1998). Budgeting in Hungary During the Democratic Transition. Journal of Public Budgeting, Accounting, and Financial Management.

Manasan, R. G. (2016). Assessment of the Bottom-up Budgeting process for FY 2016 (No. 2016-23). PIDS Discussion Paper Series.

RA No. 9184 Government Procurement Reform Act.

Republic Act 7160 or the Local Government Code of 1991.

Schick, A. (1990). The Capacity to Budget. Washington, D.C.: Urban Institute Press, 1990.

The General Appropriations Act FY 2014-2016. Accessible at: https://www.dbm.gov.ph/167-publications/general-appropriations-act-gaa/496-general-approp riations-act-gaa-archives

The 1987 Philippine Constitution. Accessible at: https://www.officialgazette.gov.ph/constitutions/1987-constitution/\#: :text=We\%2C\%20the $\% 20$ sovereign $\% 20$ Filipino $\% 20$ people,posterity $\% 20$ the $\% 20 \mathrm{blessings} \% 20 \mathrm{of} \% 20$ independence Thindwa, J. (2006). Entry Points for Civil Society to Influence Budget Processes. PowerPoint presentation during the training/workshop on Budget Analysis and Tanzania's Participatory Public Expenditure Review (PPER) conducted by the Research on Poverty Alleviation and the World Bank Institute.

\section{Copyright Disclaimer}

Copyright for this article is retained by the author(s), with first publication rights granted to the journal.

This is an open-access article distributed under the terms and conditions of the Creative Commons Attribution license (http://creativecommons.org/licenses/by/4.0/). 